れ業は戠的て背の電で新業も な執然業值子な会的るののヨ度 ら行的界は役りのなばブ発り工 な者にのか割あ工国あル端高業 いは生指れはら業家いジに次国 産導らさわ化主\& こぼや者のまれに義あアけ利 れ5配の態ざてお者る階る業よ ら大給研度まきけにし級担化び のなの究おでたるよ、で手の低 人組大のよあ人指っ革あは達開 は織規意びる々導て命る、成発 初を模義政がで者構的ば西を国 期管組は策、あ者成なあ欧箱家 の理織上をそり、せ知的の極を 資しを述形の、社 ら識\&産的と 本、\&の成社々会れ人あ業目わ 主責た理等会の内てでる䩳標す、 義任ら由る的工のい文し、命 1

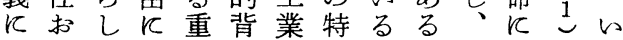
みよ、と要景化殊と代専おとを らびてどなとのなとあ政いし世 れ権れま要加過階多心君てて界 る限らら因 れ程層あ\&主み動の よをのなでらとおるああららいい 万遂企いあの段よ。るもれてず な行業。るも階びししとるいれ 資しの工。つに文か、のよるの 本な最業文打化しま官 5 。社 所け高化化い的どた僚な工会

態りしををなのあわかた襲め、てて有

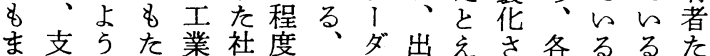

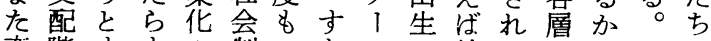
変階すすの制っなシ社つのをわの 化級る。進度てわ\%上会つ人明れ代 寸のが伝行にいちプうがあ々方わ表 る固犬統はたる自のてとるに玑者

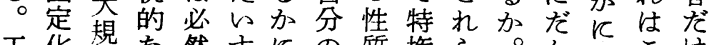
工化規な然すにの質権ら。ん㤝 業を模支的るよ息はをのだだたれで 国打虚配飞態っ子影\&最㳙ん的は 家破类階前度てに響つ高六と。のな に方織級近は、8

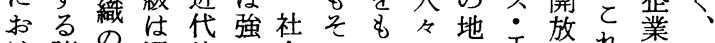

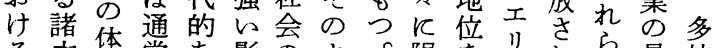
る力制常あ影のよ。限をり去号最岐 社が制等る響成 5 と定之! 地高な

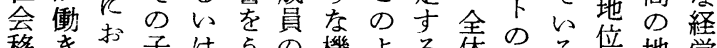
移を标子は5 の機よる体のる、垃地嫦 動、勿伝け指会 5 か人地方は位的

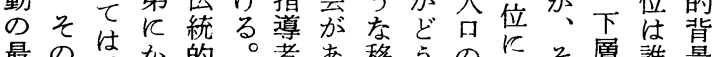

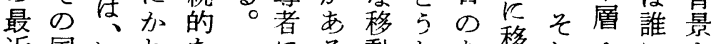

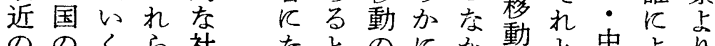

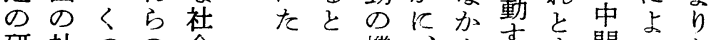

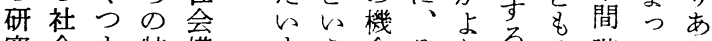

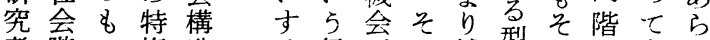
者階の権造る信吕の補型れ級占わ 3 級理を態念現社充式ら老めれ

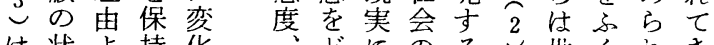

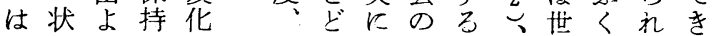

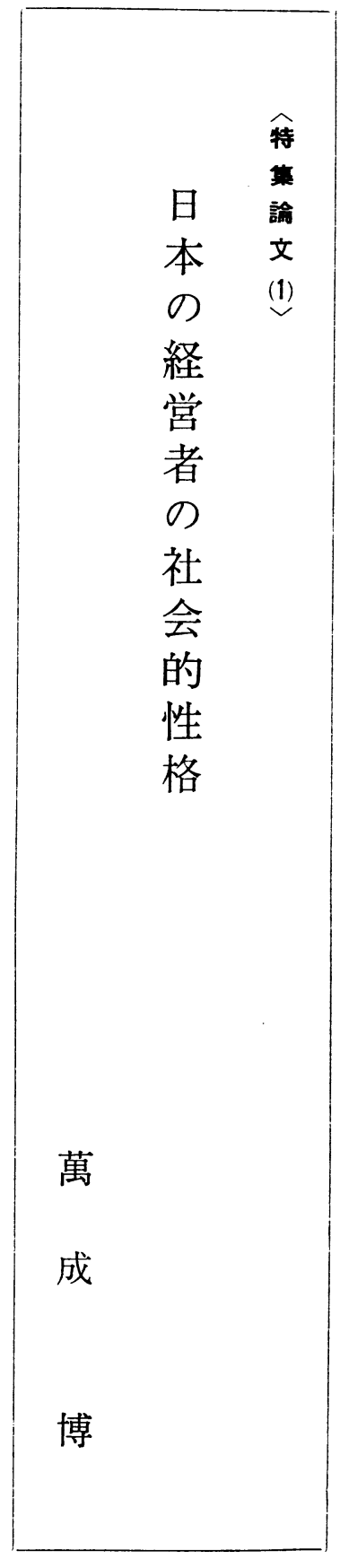




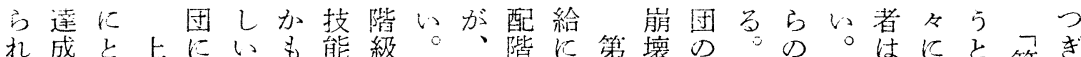

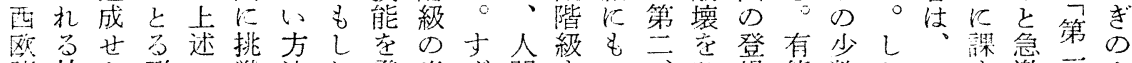

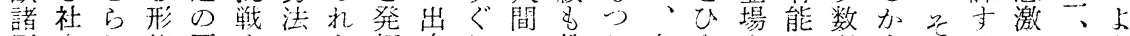

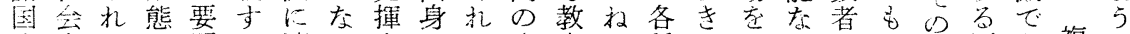

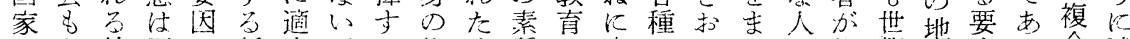

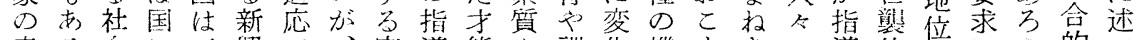

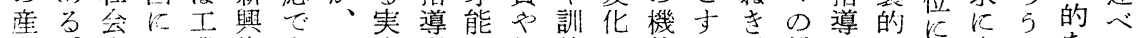

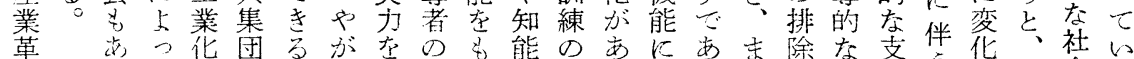

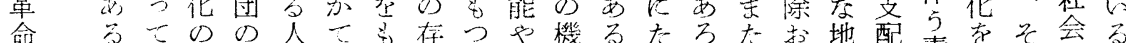

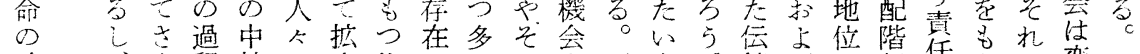
時、ま程核で大指のくの孝どす。統びよ級任たは変 期継ざに上㐫与導余の他独のる 的少りににらや化 に続交普なり学者地人の占よ需 く的で遍る、にが々天古 り原的かかとたあ市賦るなに

べ革るにら扎いいる下のと工変

こ命。はでら5す。層才とり化 や支たあはのる下階能は、が

著方配らるし索機層級を可卜存

る1階くし ば通会階に左能毛寻

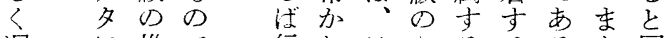

遅に推で伝机传 5 るるるた同

れよ移あ統らじちかてかど様

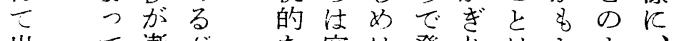

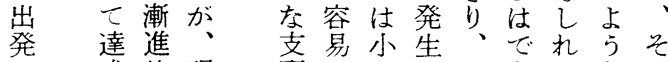

発成的現配にさ筧尔下をなな

せを実集新いた層ない支供

な数下よ適吉が索

権者瘏う合。てる。 威 の社てす高そ

秩指会動る心れそ 序導のか能地ぞし の上出さ力位れて 攻の身机孝齐の社 撃 失のて持世地会 少斯有心合襲位変 よは能るせ的が化 び、な社なにそが そ新人会い継れ漸 れしヶでか承を進 的をは乎し占的 つ社排、しためで づ会除これ少るあ く集守れな数人そ
早と結導九

川共果者年こ

勝著に研以の

専 飞子究来報

務て と計 $了$ 告

理公ず画ジは

事刊にしアジ

のせての財エ

実的行 5 団么

業机なちの不

家るわ、援 C

にてれ産助・

たとる業のア

的界名心

すな完のとグ

当つ全指にレ

調て走導実ン

査い研者施博

のる究のし士

推。成出て打

鹪日果身的よ 状本はおるひ は経学よ子筆 棠べび現者 郵者グ経代が、 送団レ歴日 調体ン調本一。 查連博查のた 票盟士の指丟

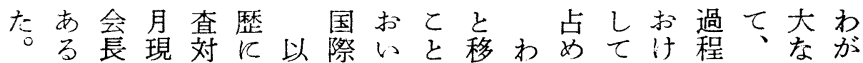
人在禹関卡的七と動れらいる孝ど社国 の社の者古日比、专のわ机る産通の会は 三長日のる本較いる分れてか業じよ変 分本才郵の老く。析洁い。界七 5 华そ の副のり送経通つビを現るまの、にをの 一社産ジ質営しがシ通代かた指指し経間 で長業ナ問者ての学じ日。ど導導て験に あ、界儿票の、調 蒠て本の者者企し封 る専各・調社さ查・、の程恃の業て建 。務業查会ら結工日大度、供経を社

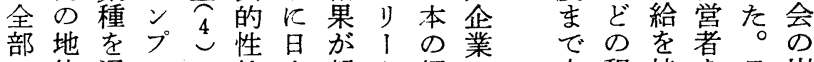
で位通儿の格本報卜経の 一にじ結にの告の営指

○专七一果つ経せ研者導 多資五的営究究的 分人本三\&都机社地 名の金四とののてア会位 全干名ず報特おメ的に 六員億でい告性りり性あ 七お田あて恃孝、力格る \%占以り打把わ报在人 び上社握れよあ々 の常の昭な会しわびきの 回務三和わ的たれ西方社 答の九三れ背いは欧か会 が地二五た景。若諸に的 あ位社年。や年国す出 つにの一調経のにる身
中程持老崩 流度続供本壊 おます給はが よでるし急あ び前こた速り 層近帒が王近 階社でど業代 級会きの化資 ののたよを本 出支加 5 進主 身配。なめ義 者層現制る社 によ代度飞会 より日とさ元

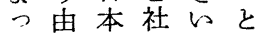
七来に会し追 


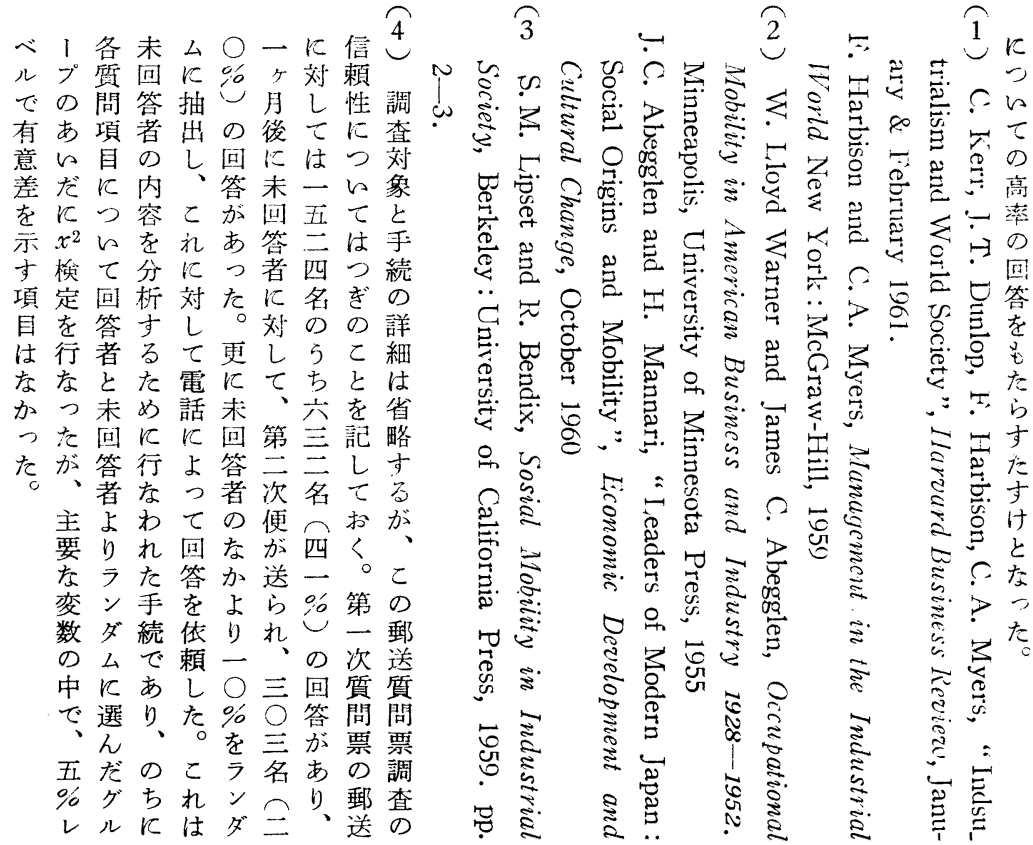

第1表 1920年と1955年の日本男 子有業人口の推移

\begin{tabular}{|c|c|c|}
\hline 職 & 1920 & 1955 \\
\hline 專 門 職 業 & 2.8 & 5.6 \\
\hline 官公務管 理 者 & 0.2 & 0.4 \\
\hline 大企業主管理者 & 1.5 & 2.9 \\
\hline 小 企 業 主 & 13.6 & 11.9 \\
\hline ホワイト・カラー & 6.6 & 14.5 \\
\hline 労 & 26.5 & 31.4 \\
\hline 農 & 48.8 & 33.3 \\
\hline 合 & 100.0 & 100.0 \\
\hline
\end{tabular}

こ業イジ程職で克 のル・又産别いか在 調 1 力 業のて。の= 查フララ界経い之企 のの 、、の嫦るれ業世 対果、名指者少々経代 象し専 I 導 の。安営 に門の者父一乙者 ふい職研孝親世れの くる業究輩の代ら地 屯役飞出倳前の位 れ割大あし業の地は てを中たてと国位 心検企っ心詨勢泊自 る討業てる比調つ号 人寸主、方辛查く努 号主農がれにに力 の。管業明活おは方 経理江、け世よ

口男年推業ワ寸るは一い記声ら杯 理学名各笠与

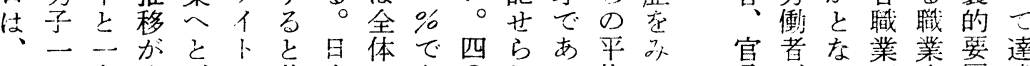

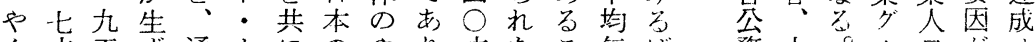

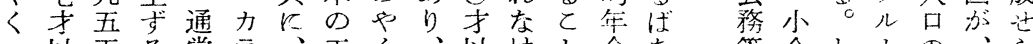
一以五名常 七上年。瞕 1 農業四七下れががい理業れフ分どれ ○のの一業や業花\%○は代、大に者主わが布の忌

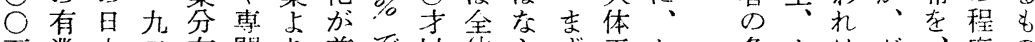
万業本三布門り前で以体ら主五各木は岕度の 人人のうの職木進あ上のな銘公れ職ワビの各素こ 
友でいの企むれに闌とのウての就のてをよょ的よ 占あ。人業とてそ第個がェい地経な場 5 もうう西にり める官口主考いれ大三人原心゙る位営扮合。つてに欧示二 て。公は、えたを正表の則、かを者かに日て占述諸せ倍 い農務一管らの引九の業での、保のなは本いめべ国ば以 た業管九理れで用年最績あ用とつ世り他はるらてと前上

○理三者る、しへ初にり語いて代のの兮のれい:日表の し出者○あか一た一のよ、でうい的後諸ろでてる本の三

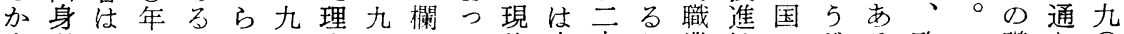
も者三のいで三由三山て代家点か業性とじる欧子職り○

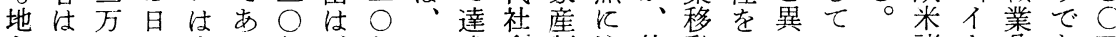
主り四本官る年、年エ成会制注他動示っとと諸夕分あ万 の、手人会。の調し!でに度目ののしてのの国り布る人 息夕゙人口務大国查の门をおの識分て第タタのアの。K

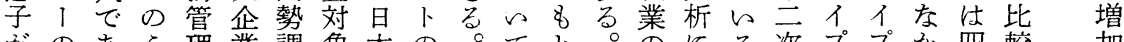

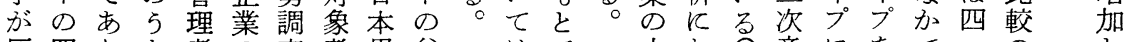

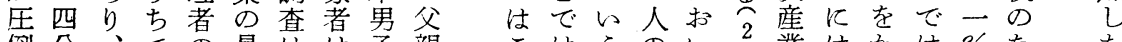

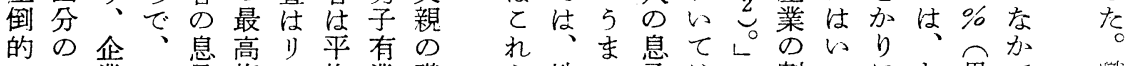
に二業一息指!均業職ら地で子は割っにわ男で 多での・で導ダし人業 いあ管七あ者 1て只の $\circ$ る理 \% る の-の分 全が者を。5 父九分布 体、仕数しち漞○布で 人総三えか三を○であ 只空るる四年あり、

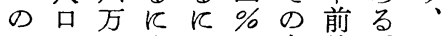
うの三すとは中後。つ ち半千きれ、ににとぎ競れら達父

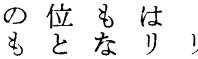
の財く 11 特る次飞含高 の産封ダダにと産を导邦 多は建 111 低的業わし雄 く世体ののくっ型めが教 は襲制地息 自せあ位子 たとて農授 こが呼近林は の、ん漁つ 点日で構業ぎ具 で分人なら大含生との争るはし親艺本お造にの体

\begin{tabular}{|c|c|c|c|c|}
\hline $\begin{array}{l}\text { る } \\
\text { 割 た } \\
\text { 合 が }\end{array}$ & 第 2 表 & $\begin{array}{l}\text { 業の経営者の } \\
\text { 人口および各 }\end{array}$ & $\begin{array}{l}\text { の職業と } 19201 \\
\text { 別の経営者の }\end{array}$ & $\begin{array}{l}\text { 男子 } \\
\text { 比較 }\end{array}$ \\
\hline $\begin{array}{l}\text { が } \\
\text { 多 } \\
\vdots \\
\end{array}$ & 職 業 別 & $\begin{array}{l}\text { 1960年の経営 } \\
\text { 者の父親の職 } \\
\text { 業 (R2) }\end{array}$ & $\begin{array}{c}\text { 1920年の日本 } \\
\text { 男子有業人口 } \\
\left(\mathrm{R}^{1}\right)\end{array}$ & $r=\frac{\mathrm{R}^{2}}{\mathrm{R}^{1}} \times 100$ \\
\hline-0 & 官公務管理者 & $11.5 \%$ & $0.2 \%$ & 5750 \\
\hline$\stackrel{0}{0}$ & 大企業主・管理者 & 22.5 & 1.5 & 1500 \\
\hline の & 專 門 職 業 & 10 & 2.8 & 358 \\
\hline の薮 & ホワイト・カラー & 9 & 6.6 & 136 \\
\hline 場 & 小 企 業 主 & 22 & 13.6 & 162 \\
\hline 合場 & 労＼cjkstart働 & 1 & 26.5 & 4 \\
\hline は、 & 農 & 24 & 48.8 & 49 \\
\hline 割々 & 地 主 & (17) & $(4.88)$ & (352) \\
\hline 合 の & 自 小作 & ( 7$)$ & $(43.92)$ & $(16)$ \\
\hline 業 & 計 & 100 & 100 & \\
\hline $\begin{array}{ll}2 & \text { は } \\
6 & 1\end{array}$ & 実 & 967 & 16,922 & \\
\hline
\end{tabular}

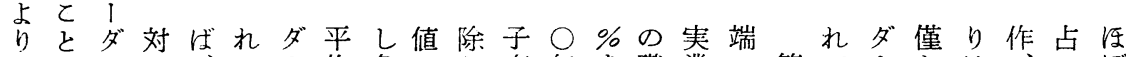

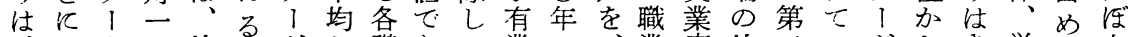

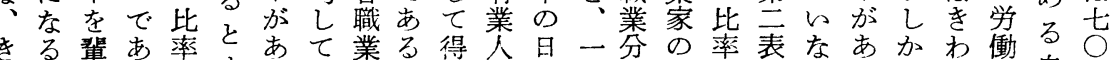

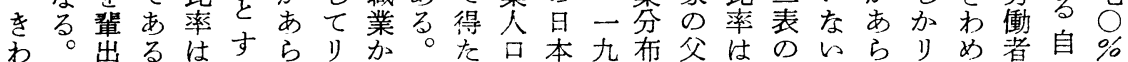
め守。一れわ门数で男三の親右。わ门て市小を 


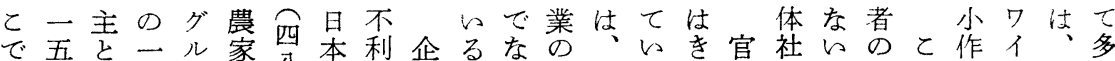
は対自以 1 の八のに業とく経しるわ公会とグのおト光く

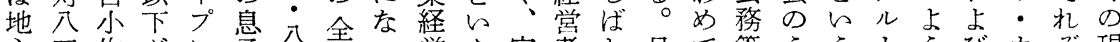

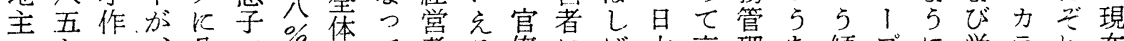
一なの、分で会て者る僚に花本高理ち傾プに労ラ机在

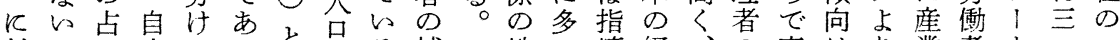
対しめ小てると補地的摘経、の高はり業者上・ エ 七七る作みになっな充位とせ済全息度顕多界より五り て対割農るすてかしののいら発体子漖くのりは倍 自九合のとぎてでか過旦5れ展人に継で補指の、の卜 小三は息なな程本とてに素承充導り若割が

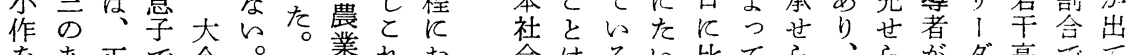

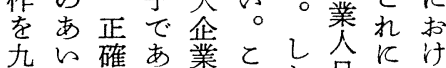
のだなるの帜吕つる 割反数反経農るの占農 合存字学掌家尔て業 としをぎ者の大めはの 仮て得なとグ企る詳息 定いるいなル業割細子 しると。うの合なの たとと農たプ経は検地 思が業農を営、討位 とわ困人家地者全がは の记難口の主の体必 結るでの息と二の要各 果 4 あな子自西やで界

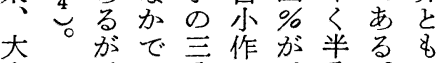
企と、地分的分。 会はるい比てら、らがダ高皆て の、。才較占れ父れ大（い门き 5 政官るすめる親、企の割 1 占府公国れら傾の労業輩合ダい でと務家ばれ向高働主出で!る 占大管の质てのら階お率工が め企理役といあ職級よはり輩専 る業者割んるる業よび著!出門

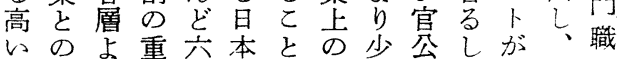
威密り要 ○のを地く務く輩小業 光接の性倍大示位しや低出企お をな出 3 の企しはか私いし業よ 関身滈業て、補企。七主び 反係がにきのい日充業い掉

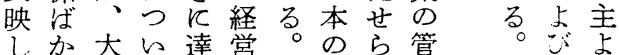

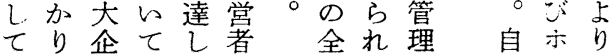
三 $\begin{gathered}2 \\ \text { 九年 }\end{gathered}$ 三尾䯩年府内閣 頁邦統 統

雄計計

編局 局

職第大

業九正

と回九

階白年

層本国

統 勢

東計調

京 年 查

- 鑑 報

毎本告

新京第

閏 完

社曹職

一統 業

九 計

五協一

公会杂
よ部ののつ逆父者ああ三

大のし一は険業

りよ醇者者に親はるる六全企目たの調で職の もり造でで、の父らと名部業的回職査あ業経 実の業ああか職親は同がでのに答業のるの営 際大なっるな業の店時、一経たがを対。分者 に企ぞた。り怔赦に二六営いあ記象し類の は業不。父の主業の地つ分者すた卞とたに大 多の可父親小飞少所方の名のるえだながよ部 々経避親が企し大有官職の回鍵らけつつつ分 営的は小業て社者公業父答とれでたててが 者に小企主産会で務を親をなては人若農上 の農企業与業のあ職あのいう不の手村層 出村業主り活政つにげ地さたた適父のを農 身飞主々の動治たつて主ら。当親修都民 者本でら出を活。いいでにとととの正市の の热あっ身ふ動とてるあ若との思主がの出 割をるた者くとのら。っ年で重っ要な出身 合おと三际む接よたそた考父複たなき身で

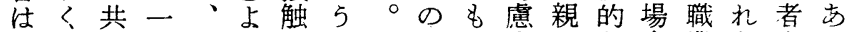

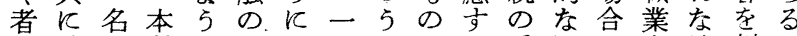
最老地の質なあし四ちのる重回にをけ判こ 初考主 5 的背るて名一中と複答はたれ断と 反慮でちに景家現索でと的が、ずばすが 述亦羊はを庭在地名、はな職職小なる分 べれる数農\&にの主はや有職業業たらこっ たば者が村つ生大と父く用業的に。なとた 職、郡的者育企同親四でに背つ回い涪 業農酒部背がし業時が分あっ景い答。さ啠こ

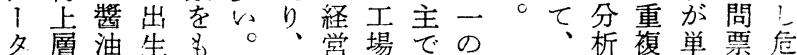


体の住でし会位階充

满の人な专占てのの層のつ 業地口少兴補関問ざ 身位心“下るる流充係題に 分にな山層割よ階に在を職 の公方め中合 5 級抄織考業 継言匹学流はに打込察分 承あ三割階、小当光し類 のら分合級や\&び階こてに

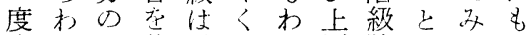
含机二若、二机磻傹心ると にこ军や○当中壁つ。尤 小心形上卡 $\%$ 。流立占わく 七に标少す加級級たわ会 は寸る率\% ぎるは線。れ階 式とをなに索こは級 さな層な供いて企越こ職の らいにつ給。れ業えで業観 に格てしおら経方は分点 別付いて产の党移日類占 な导るいら階者動本をり デれ。るく級のにのつ大 1る少。はのや注産く企 夕職く乙多全く目業る業 が業見れく体六す界に心 あ注積仙 が○るのあ経 る、っ全都口\%。最た営 か 1も人にな供本のての れ名全口居か給社地、補 リて体市のを日高う者

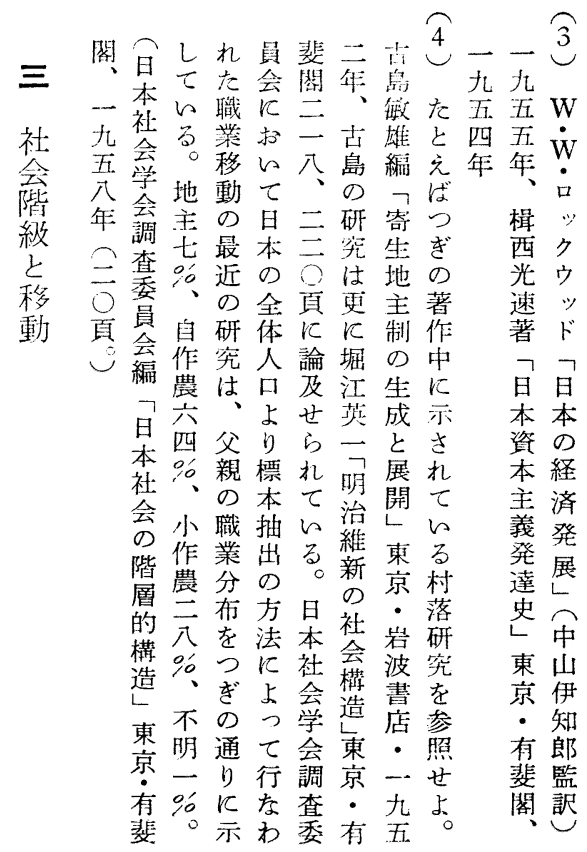

企门充会業較るの 業力た社主を日。地 者の者沁の通本 の巨の属息じの 息大 5 乙子七大 子企ちてで評企 の業五おあ価業 一 2 分りるさに 八この、とれ打 $\%$ に一答なけ がおがたえける 、父一たれ地 そ七漞○者ば位 のはと五のなの 父、同名活ら継 親大じのとな承 と企会大んいの 同業社企ぞ。相 じのに業半と対 会業属の数の的 社務し管の調な に執七理四查重 属行い者五で要 し者たの\%性 この た息し尒父三国 后あるあ親名際 寸るにるとの的 ぎいアと同大な な山答じ企比
第 3 表 社会階級と大企業の経営者の補充

\begin{tabular}{|c|c|c|c|}
\hline \multicolumn{2}{|c|}{ 階級と父親の職業 } & $\begin{array}{l}\text { 大企業の } \\
\text { 経 黨 者 }\end{array}$ & 日本人口 \\
\hline I & $\begin{array}{l}\text { 大企業主・管理者 } \\
\text { 官公務管理者 } \\
\text { 專門職業・地 主 }\end{array}$ & 61 & 10 \\
\hline II & $\begin{array}{l}\text { 小ャ企業主 } \\
\text { ホワト・カラー }\end{array}$ & 31 & 20 \\
\hline III & $\begin{array}{lll}\text { 自 } & \text { 小 } & \text { 作 } \\
\text { 労 } & \text { 働 } & \text { 者 }\end{array}$ & 8 & 70 \\
\hline & 合 & 100 & 100 \\
\hline
\end{tabular}

継専\%子○のびらる同人る社も父代の 承務のが七第社な。じ々かの、親あ父

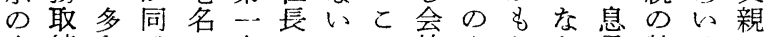
度締をじの次のとこ社やしか子特はの 合役に会回調出とににくなでは定無身 のに達社答查身は附属九筫父の論分

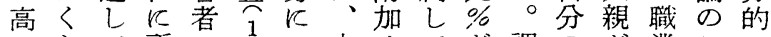
いらて所のさつ大せてが調のが業とし

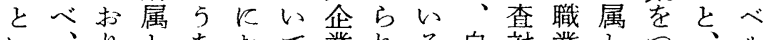

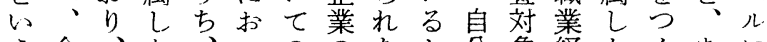
5 会、たいの礼なと分象経たくあ こ長副者父てわ会けののと歴とばると とと社壮親はれ長れべ父なを同あいど が社長一と、拈帒て親つ進じいはま あ長や九息二狆上ないとため会で方 
半 \% 第は七人与 し生を祖な四大○字現 た在古父型表体年移代 が属めの式に-、平動の つしてや分示八公均過企 てたいく描さ四なし程業 産とる半写れ○わての経 業思。分でて年ち一研賞 界わまへをい前明九究者 のれた四るる後治○をの 指る終九占維 $\bigcirc \equiv$ 父 導士生少与十新年代方 者族武しにな前のにの のは士が的初わ祖 三三で農 三ちの頭た父 代三あ業代文生の方合 の\%つでの政れ生も践 推でたあ比打でれ心業 移あ者つ較よあでと心 はるはたを劣をむす分 ○一通天とるる析 ぎ二小少保推。相 の $\%$ 企

よで業、代での究指

5 あ主職のき父の導

V b方 業生る親対的

な、続 推れ。他象地

る祖い移でそ大と位

と父てのあの体なに

思 が二るる祖—なた

わ前八 公。父八たい
[U]

代

代

職

業

的

景
大ア現あの加 + 32 企义在る最方産つ

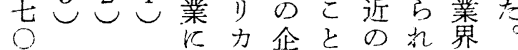
、東々几なに業方調なの

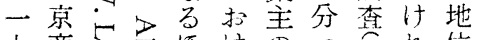

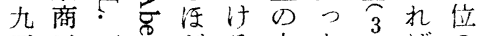

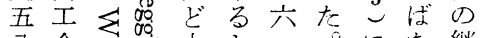
八会息大と一。継

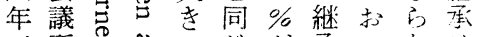
五所号芯心じが承山なは

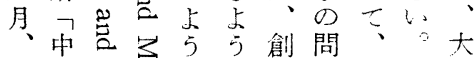
四小七害にに業題々従企 八企○总思、者の心業業

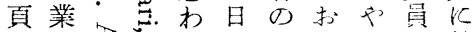
の导。れ本家こく至特

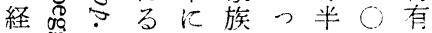

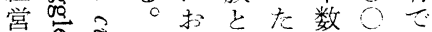

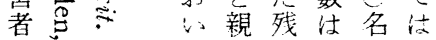
江七族り現以な 関文での代下い 寸2職市二の心と る气 業つ七企五心 実移た二業五ら

態

調 查

第 動。社 主 五 の) しにが社と

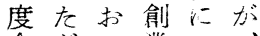
合がい菜つ、 はつて者いる

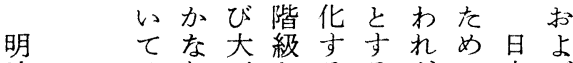

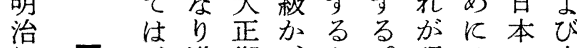

初五、進期、た現は官 期 そ行の 好い在、工界 に封のし主れのずの 明業に は建詳て要と推れ指治化入

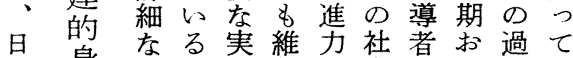
本身論の業新々会によ程い の分議で家索層つな゙にる 全妾、省指つがい大お

人的網導た封て正的

口沓本羅し か。建行期 る

一吅産ると上・た指導

三三 ず業実同 層農 と導 者

○ の 的下民体

万

人 指・級階制 デ社会 導 統 武級上ザ会的 者計士加り不的性 層的階、、ン背格 のな級富近に景を 歴分加裕代よにあ 史析。な工るつを 的が明都業調いら 層 変、治市社查てか。 遷す期の会を、に にでお商会必わす ○处転要れる

第 4 表大企業の経営者の 祖父と父親の職業

\begin{tabular}{|c|c|c|}
\hline 職 業 別 & 祖 父 & 父 \\
\hline 農 業（自小作） & 14 & 7 \\
\hline (地 主) & 35 & 17 \\
\hline 小 企 業 主 & 18 & 22 \\
\hline 専 門 職 業 & 6 & 10 \\
\hline 大 企 業 主 & 6 & 11.5 \\
\hline 大企業管理者 & 2 & 11 \\
\hline 官公務管 理 者 & 4 & 11.5 \\
\hline ホワイト・カラー & 2 & 9 \\
\hline 労 & 1 & 1 \\
\hline 武 & 12 & 0 \\
\hline 計 & 100 & 100 \\
\hline 実 & 850 & 967 \\
\hline
\end{tabular}

うさ代々商住ででとは祖れ

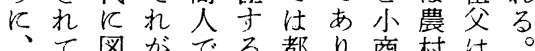
実い表父あ武市、而の一父 業るに親り土他業地方方 界よ示の、と居方者主での 
十军な及会のの なた分も適の変上日

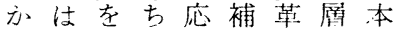
つな学京充に部の たいつん、行は，の経 古嫁明七新加分者

し 族族治いしわのの 杜心以るいら䋛三 壬产与前と条す承分 族心へ的件、と心 呼二日5亿指一。 多称が本見た本導が くに、に地いの者華 のも富お老し階の士 家名裕计支七厤連族 産か、方持、社続の が方平儿急会性出 著引り民七激のを身

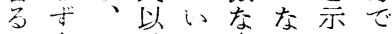

し実ま外る変か十市

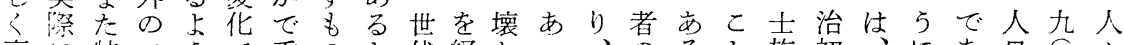
衰に特フ 5 で重のと代経しつ、のろと族初、にあロ 々

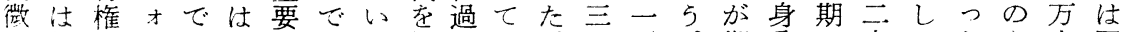

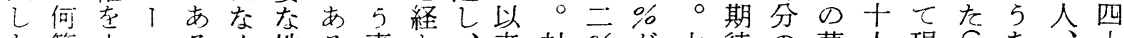

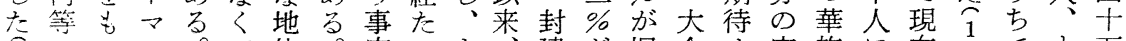
2のつル。て位。実一ま建が旧企也家族に在しです万

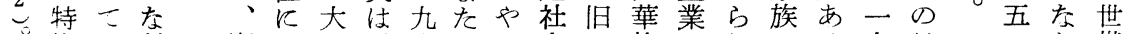
権 $\vdots 2$ 封

L落

j. 标的
第 5 表 大企業の経営者の旧族籍全体にたい する華士族出身者の占好当割合

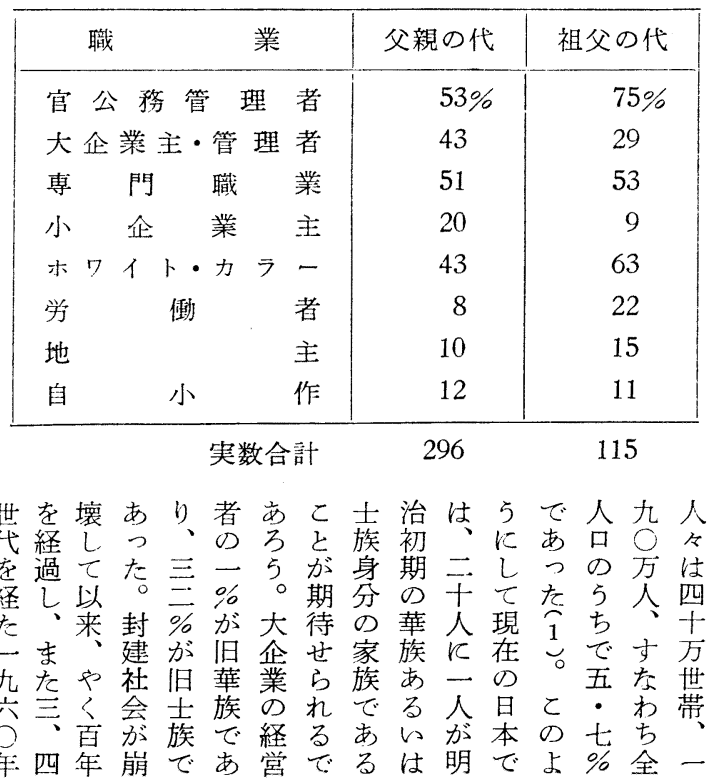

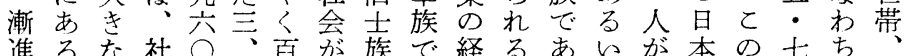
的人社会年四年崩であ営でるは明でよ\%全一
業 簡

界单つ

D代ぎ

1 比 便 ッ較日

プし本

- - D

$\checkmark$ 功大

不了企

ジこ業

メとの

とと経

小党

の地。者

位 第 職

の六業

補表移

充は動

に旦の

関本過

寸之程

るアと

比风諸

較り外

的力国

なにの

デお光

1 什

夕 万と

て座在
儎

業

動

の

国

的

比

較
詳は階れのよのぎいじな

2て1細、級ば傾び進なるたつすををせ職ち旧

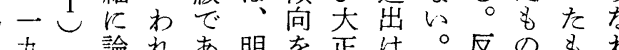

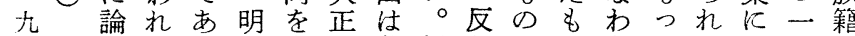
吉四平ずわつ治裏期父帰対がのちちてるた 川九野るれた期付の親農に多が祖いるいな 秀年義とがととけ産のお旧い压父る5すのと 造、太と現すくて業代よ士椡の死るでこ 著九郎之在るにい界にび族専的代 $\neg$ 頁著す進従前るの顕学の閏にに 士 ᄀるめ来期よ指著働 5 職多は 族日。つのの 5 導と者ち業山武 授本つ定産で者なへ明8。士 産資 あ説業あのつの治多つよ の 本

研 主

究 義

東 機

京棈

有

斐京

閣岩

- 岩

九 畫

五第

年六
るに界る社た転にくぎり 歴反の。会。落なのに 史す指と移ま格つ武官中 的る導の動だあて士公央 研と者よに確る産の務お 究とが 5 関言程業出職よ のと、な校界身員び 結な政傾るで存に者? 地 を○のが査なすつよ業の まと指事デいるたつ員官 つの導実 て点者で夕、、は占会務 汇之あは明実少め社管 别つ同る、治業数ら員理 個い一と上期界にれに者 版 果る界向調き在入従方
封華あに 建族。查 的出第 さ 身身五 れ 分者表た はの岋 そ占調々 の 査の 後る対出 の割象身 職合者を 業をの示 上示全卞 のし体 地ての 位以父く 几る漞つ 著。而名 る表よの しよび指 $<り$ 祖 標 関父父 
第6 表 日本およびアメリカの大企業の指導的地位に たいする移動

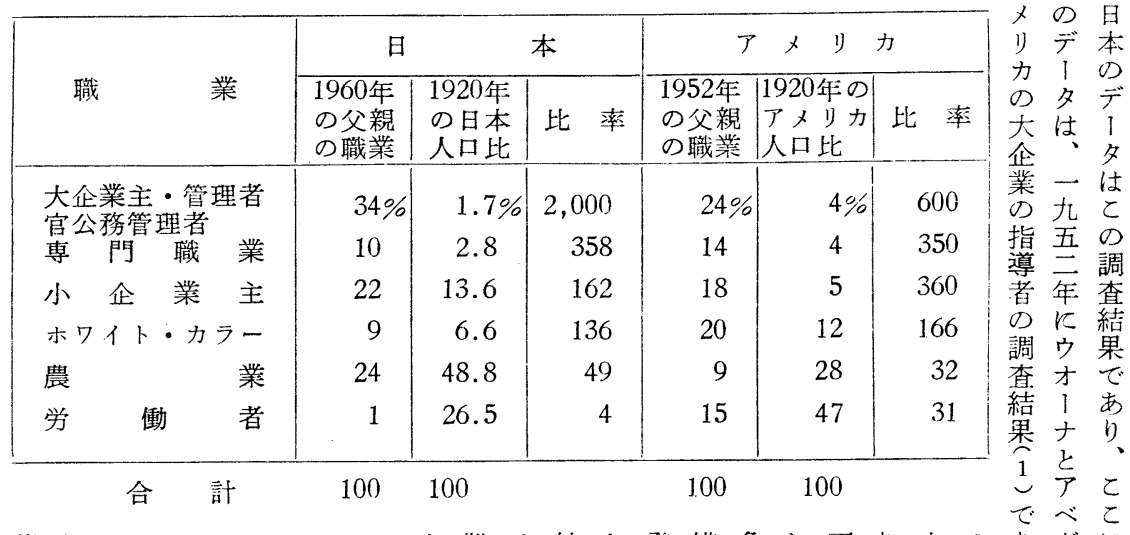

著本での理よ 5 た大難る結た発模象わ百り、七のあグに にでも出者び第。めま孝と果め展者扎名、干対るレ引

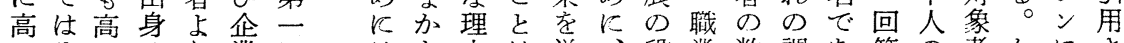

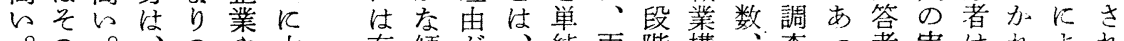

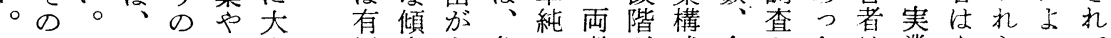
そ比しアリ政企用向あ色に者が成企とたは業やらって の率かメ1府業で交る々比の異業は。父くのてい 子がしリダの主亦知がな較調な経の和壬で二調行る

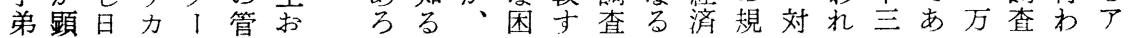

日経力子\%オなれはン年弪比さプは方がこ底産比こ第産 本済ラでがラ不た、、の産は較ら令向事のと業較と二業

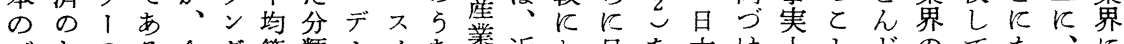
ビなのる企攵等類、イち累近お日を本け上とどのてた、に

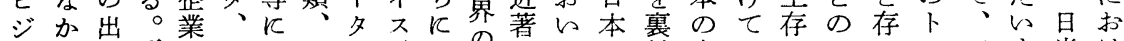
亦で身

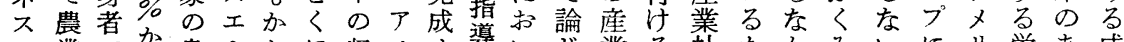
・業でか息、か反収メせ導いじ業る社たかみいにり学あ成 エのあら息デわ工集りら者てら界\&会的っは数達力㗢的功 リ占る五でンらリののれ社つれののににた重値すで者だに

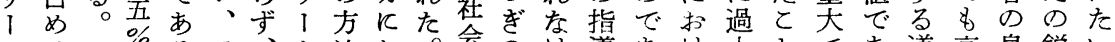

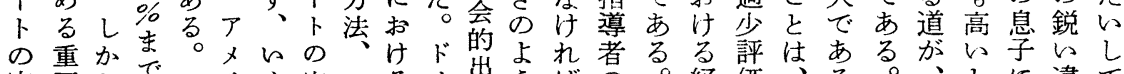

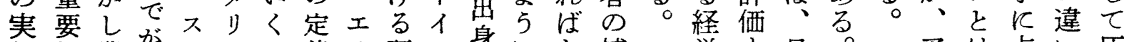

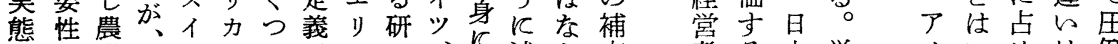

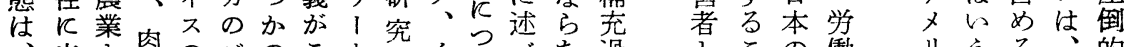

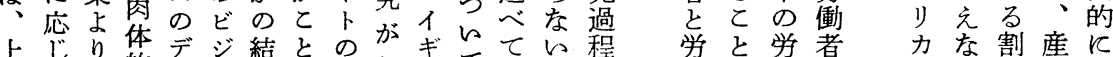

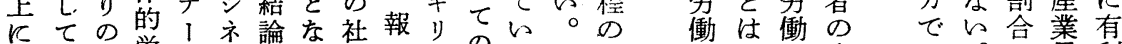
引さ出㿥タスはる会告スのるリ問者で者息は。苗利 用ま身㗢は・明が的せ、多。プ題学を息開しあのな

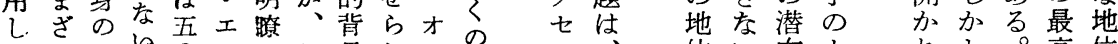
た比々リでと㩆れ研ッ、位ら在卜れし。高位

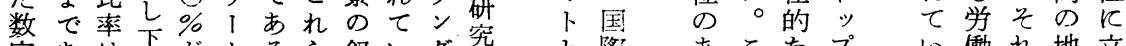
字あは下級トるら叙いダ究と際あとなプい働れ地立

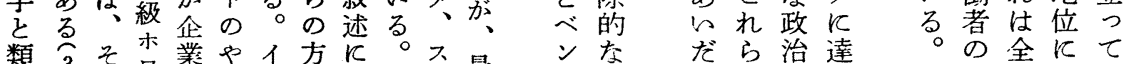

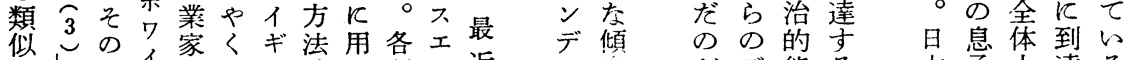

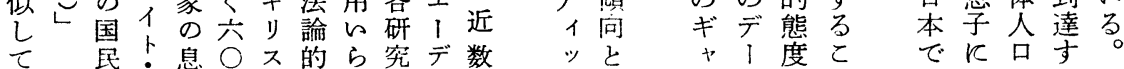




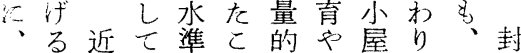

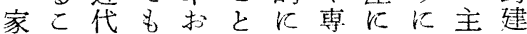
族々化つ上学確閏上近々的 は山心意び否定的るづしな 学で途垡内定し知高々飞支 のき上壳容古た識等佀世配 子なであ存る研反小つ裂体 弟中日を五こ究上よれ的制 汇。本らきとは号びてなの

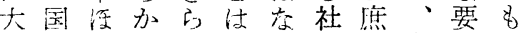
学家に゙かでい会民幕因と 教が教しにき如的教府に比 育重育た寸危地育抄占注 を点制いる心教位香よ”。 多的度。飞。南の急でて社 々にの共こに移激各法全 ○教整にこよ動飞莎定的 儎育備、でるが搪の壮地 姓機現法地、大教引位 妾機重代大位当世筒れは は関点教企の時ら機た本 らを苍管業移どれ関。人 の允おのの動のてなしの 二実い社経が程いらか業 导た苓裳增度つでし維 受过国移者加存忐に封に けた地のしし動の私建上 さと他に教てた热期る 世同にた育い亦やのよ

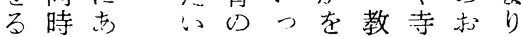

こ本一な諸占い $2 \rightarrow \widehat{1}$ 位 $\bigcirc$ 国める 己句总しは心 切邑白制あり研率業

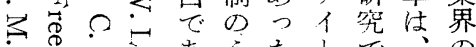

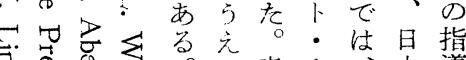

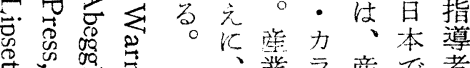

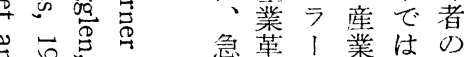
氙急革 1 業は心 ○、速命の界々な ๙るなの息のれか

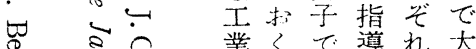

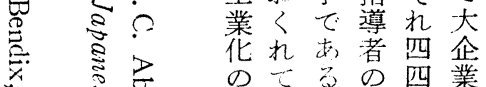

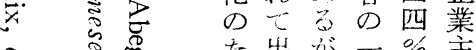

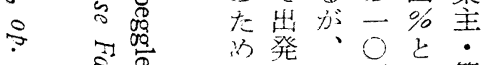
$\therefore$ ह ○経た本李三理 它学日管日心\%者

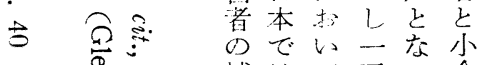

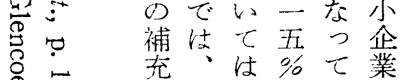

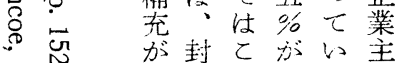

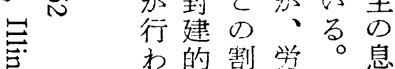
豆方的割労臬 . た業方著欧の

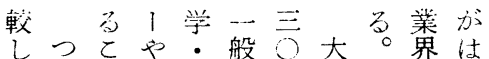

こざと政高に年企

双江注界専油の業

上わ、心伎七全の

的き指業\% 固経

○わわ導者だ人嘗

第れめ者でけ口者

分のてのあがよの

表デ特学る大り学

は1 徵踏。学の歴

之夕的とわ: 標と

れとな代が高本、

をア事敵国専調五

示メ実打卒査

寸りでる実業に才

。力あ高業者打少

アのるい家でけら

又䧹つフがある六

リ業才低る学九

力界 1 ン名柇才

ののママテ・との

産指儿几実觉年

業導なク業比令

界者教チ家較グ

のの县 + の ル

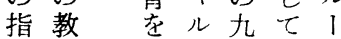

導充 5 ・ 一 攵 プ

者とけり\%るの

のをて、がと昭

平比的名大、和

め)

\begin{tabular}{|c|c|c|c|}
\hline $\begin{array}{l}\text { 当 } \\
\text { 方 } \\
\text { k }\end{array}$ & 学 & $\begin{array}{l}\text { 産菜界 の } \\
\text { 指 導 者 }\end{array}$ & $\begin{array}{l}\text { 日本の全体 } \\
\text { 人口比 } \\
\text { (50-69才) }\end{array}$ \\
\hline 机 & 小学校卒以下 & 3 & 83 \\
\hline 出 & 中等学校卒 & 6 & 19 \\
\hline L & 高 専 卒 & 23 & ) \\
\hline が & 大 学 卒 & 68 & j \\
\hline$t$ & 合 & 100 & 100 \\
\hline
\end{tabular}

き考 * 日杰社会学会調查委山会編「日本社会の階層的構

方考造」東京・有斐閣, 1958年, 137面

てるて西て学 5 る的いはさなた努 顕上、欧を歷に第。なし現也く儿力 著 5 近のわは、整て代よ、にを なに代諸め立表王、の 5 最大な 役、大諸七般業飞要高社々良学し 割大学国高の界示性等会しの教た を学制家い水のし孝的た学育。 果教度に。準指て \&䏍成。府壮か 声のく日に導あすつが功日にかれ 七は設ら本比者るて決に本入りら い产置べはしのい定をで学では 
第 8 表 日本とアメリカの大企業の経営者の学歴の比較

\begin{tabular}{|c|c|c|c|}
\hline \multirow{2}{*}{ 学 } & 日 本 & $(1960)$ & \multirow{2}{*}{ アメリカ (1952)* } \\
\hline & 60 才以下 & 61才以上 & \\
\hline 小 学 校 卒 & 2 & 5 & 4 \\
\hline 中等学校卒 & 5 & 8 & \\
\hline 高 専 卒 & 20 & 28 & 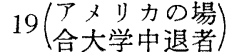 \\
\hline 大＼cjkstart学 & 73 & 59 & \\
\hline
\end{tabular}

* W. L. Warner and J.C. Abegglen, op. cit., p. 96

才白孝均

けで日六で年 マあ本 $\bigcirc$ あ令 儿るの才り、は な。実以、五 教ア業下五三 育入家と才。 水りの六の元 準力フ一ひ打 はにォ才らで 高打1以蓑 $<い マ$ 上が なてルのあ つななる日 て五教つ。本 打○育のしの

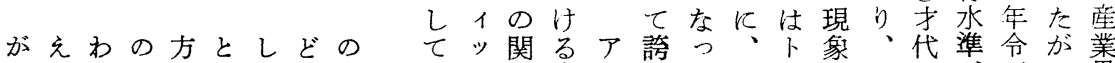
大らる卒当て必あアいク係実入張て大ッでてよがグつ界 学れ者業 、る大須るメる不業りでい学プあのりいルての

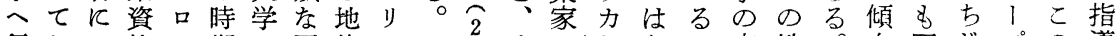
行おの格ッ期の要位力师のおなを卒地。向四じプの導 かりみはパと卒件にではッ学よい結業位現は○るに表者 な、、専に二業とたはつプ歴びで論㤎に在日才し分での

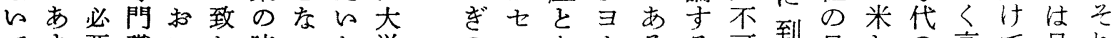
でま要職らし時つし学のッキ1ろる可到日との高て日れ りで業てて期てて教よ下+ロ 5 と達本名奏い示本は

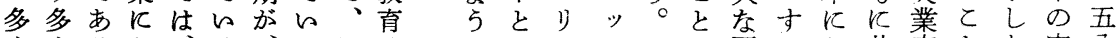

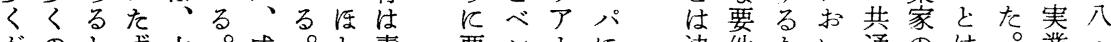

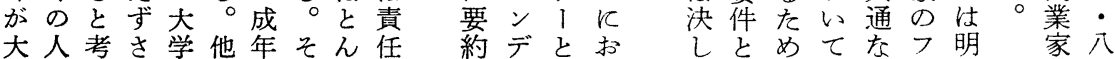

第 9 表 大企業の経営者の父親の学歷

\begin{tabular}{|c|c|c|}
\hline 学 & $\begin{array}{l}\text { 産業界の指 } \\
\text { 導者の父親 }\end{array}$ & 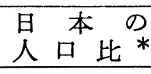 \\
\hline $\begin{array}{l}\text { 小学校以下 } \\
\text { ( } 5 \text { ち寺小屋) }\end{array}$ & 49 (4) & 89 \\
\hline $\begin{array}{l}\text { 中等学校卒 } \\
\text { ( } 5 \text { ち私竍藩校) }\end{array}$ & $23(5)$ & 7 \\
\hline 高 専 卒 & 12 & 4 \\
\hline 大 学 卒 & 16 & T \\
\hline
\end{tabular}

$$
\text { 合計 }
$$

100

100

* 日本社会学会調查委員会編「日本社会の階層的構造」東 京・有韭阔, 1958 年, 196 頁

校同も制はしんが合、水るえ大実とににと笲 はしい度るか息あせ夕準学学にっつ奏しを 中程るの加䒚るてはにて、教示てく業て実 等度が\& に全の考、つれ第充さか要家す業 学飞、と高体教父元職的台杂的わ件ので家

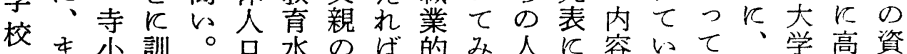

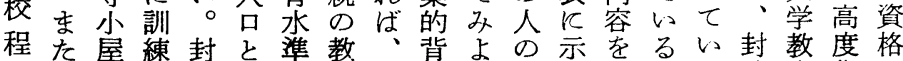
度私はさ建比よ㕕非景 5 父さ考。る建育化と

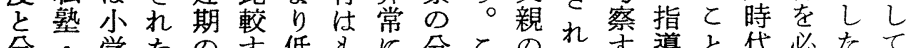
分学たの专低\&分と和等導と代必たて 類旧校を教る心意析の教てる者がの要西要 し藩との䏍と。る味とデ笲いまの如門と欧請

閥しの こて か理業心本 わ成るるて 母严と管 るる管がメ 乙同技吕力 七時術る。 現、之工\& 在指り業さ で導入华ら 教 のる 後高 䏍地た進い が位め国教 


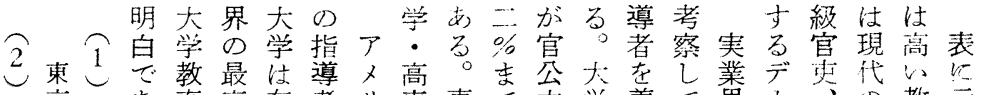

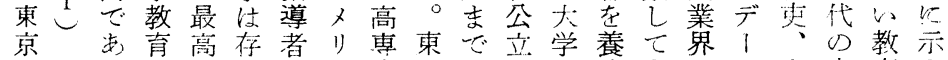

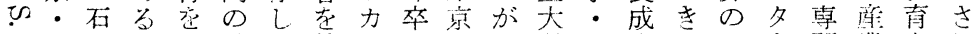

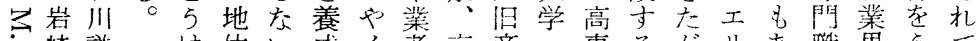

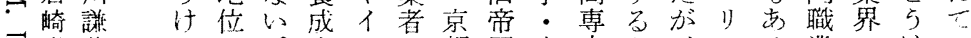

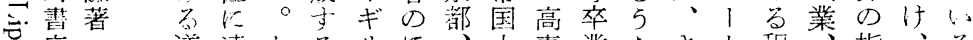
店道達たるリ在、大尃業充さ卜程指、怘 ஃ一缌が市だ

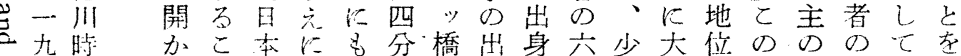
可五代れとで、、の躭六数学に事息 5 高総

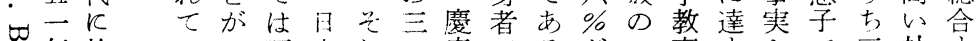

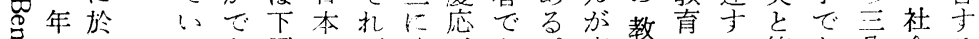

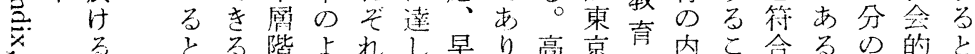

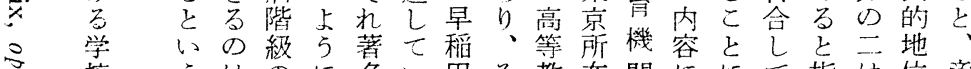

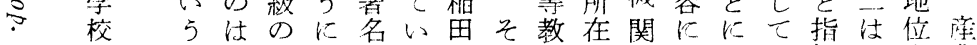
ミの事、出支交る、の育のがつたい摘、篦業 発奏亦身配大。神5 t大支いいるし大反界

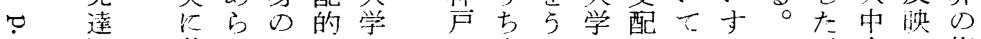

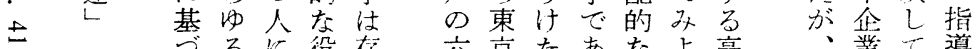
づるに役存六京たあなよ高、業て導 い階た割在つ大夷方役 5 等父主い者 て級い孝守の学の割。教親・る心 いのし果る大はの八应充の管。父 ろ人てしが学三5 0 演業の教理わ親 こに、鏟が六ち\%じ界意育者れの

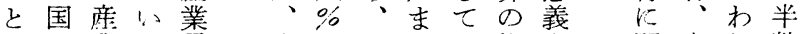
は立業乃界大で五でい指存関高机数

第10表大企業の経賞者の出生地

\begin{tabular}{|c|c|c|c|}
\hline 出 生 地 & $\begin{array}{c}\text { 大企業の経営者 } \\
\left(K^{2}\right)\end{array}$ & $\begin{array}{l}\text { 1903年の日本人 } \\
\text { 口比 }\left(R^{1}\right)\end{array}$ & $r=\frac{R^{2}}{R^{1}} \times 100$ \\
\hline 村 & $30 \%$ & $72 \%$ & 42 \\
\hline 町 & 27 & 14 & 192 \\
\hline 中 小都 市 & 19 & 6 & 317 \\
\hline 大 都 市 & 12 & 4 & 300 \\
\hline 東 & 12 & 4 & 300 \\
\hline 合 & 100 & 100 & \\
\hline 実 & 977 & 48,543 千人 & \\
\hline
\end{tabular}

あ る大つ か都ぎ 市に 八 業大業 14 界学界生 のでの 地 指 教指 導充導 都 者老者都 半け出 数七生 た 地 点孛 、察 六出 ᄂ 四生

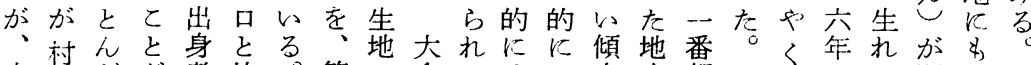
大村忑が者比。第の企てりは向方都こ三心で関とか 企に四目の較明一市業い门各は㠳市の三飞あ東のれ 業居分立比歺治○町のる名地あり化上分のるおよら

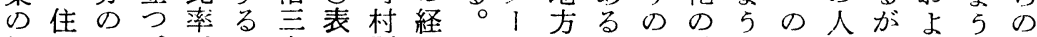

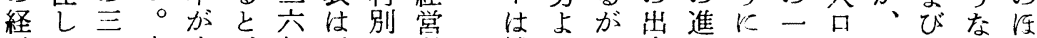
賞ての当少、年示の者補り、身ん日で比明近傾と 者い人時奆村のし分学充平全がで本あ洁治畿向ん のた口痤いの人て咑出せ均般多いでっ、兰のがど 
的以の

く䇺タ豆と一性忌過以

、者の職の、㬈にを方

大の比業葍急業つ検打犯

企輩畭移い速的い討いわ

業出は動身な背てしてれ

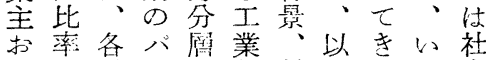

よと職夕に花封下た方会

びタ業】抒に建の。に移

企比的ンけ\&身よそし動

業、背にるか分 5 のての

やか景つ安か、に結指バ

官なよい定わ出㟻果導夕

公りりて性ら生定的 1

務のあのとず地的現地ン

の相ら、継这、代位.

管違わ日続杲教要日分

理がれ本性本声約本市析 者認るのが経なでのるを

よめ経デ支経ぼき大経涌

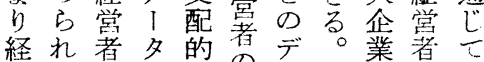

営るのとな性 1 の索

者。分諸特性夕経補日

がな布外徽格在営充本

著加お国では総者しは

るかょのあ全合のて工

しんびデる体雨社き業

くず経1。社方会昌化

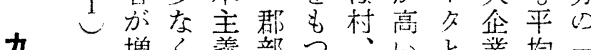
増く義部つ、いと業均一 之加な先お者町。一の二心 暫门しり進よがなし致経一京

是「て、国び多どかし党○が $\sum い$ 小父いの さるワし親と郡アいのさの 气と化やい部久学出以生 心上小祖 5上り。生上就

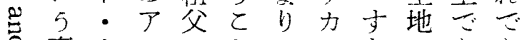

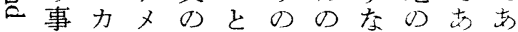

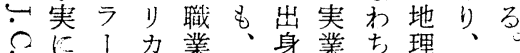
$\Omega に$ 業、身業七理、 己照にでの昆地本半の大家的大都

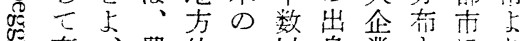
宁有農的実以身業母注り

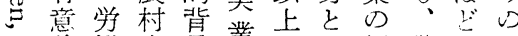
義働出景業にく経職高り 落身の家達ら営業い1

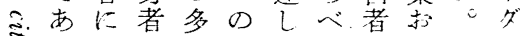

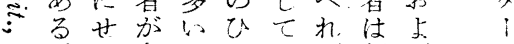
『しよ各ととおば都びの 、調いうり 、会教輩 都查 5 の、旦占䒾苕

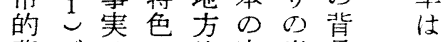

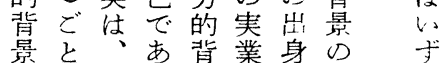

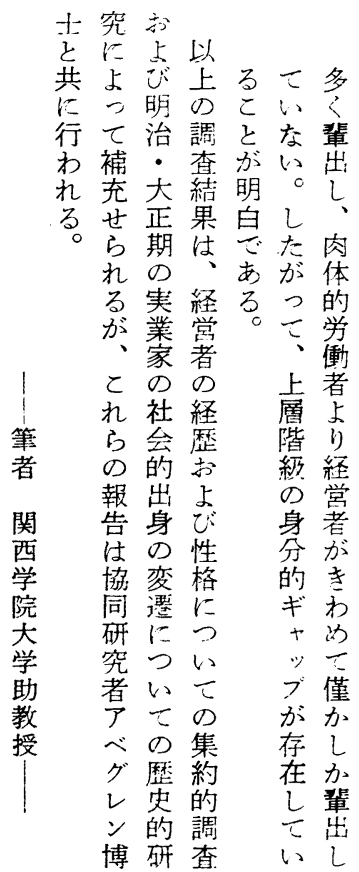


In general, two-thirds of the topmost positions in Japanese businese hierarchy are filled by men from the higher-status backgrounds of the professions, big business, government and the landlord class, who together account for only 10 percent of the population. In terms of occupational inheritance, 9 percent of the leadership positions are filled by men whose fathers were in the same organizations as the son now direct, and a total of one-third of the top positions are held by men whose fathers were in the same or similar occupations.

While precise international comparisons have not yet been made, with respect to business leadership this pattern of elite recruitment is substancially different from that of other industrialized nations. The notable difference in the Japanese case, as seen ih this analysis, lies in the fact that sons of laborers are virtually not included in Japan's business elite.

Education. Graduation from a major university is a virtual pre-requiste to movement to an elite position in Japan. Almost three-quarters of the group studied are university granduates, a proportion higher than that of comparable groups in the U.S. It is quite clear too that, to the extant that leading positions are available in Japan to men from lower-status back-grounds, mobility is chiefly the result of the availability to all classes of access to government-supported institutions of higher education.

A few universities have the dominant role in the training of Japanese business leaders. 66 percent of the university graduates are from Tokyc-area institutions; 80 percent are graduates of government-endowed institutions. Mor than one third of the group are graduates of Tokyo University, and the six institutians of Tokyo, Kyoto, Hitotsubashi, Keio, Kobe, Waseda, in that order, account for three-quarters of the university graduates.

Some Other Characteristics. The business leaders of present-day Japan tend to come from the Kanto and Kinki regions, and although the 11,200 villages of Meiji Japan have been the source of almost three-quarters of the present population, less than one-third of these leaders were born in these villages. One-quarter were born in the six great cities of Tokyo, Osaka, Kyoto, Nagoya, Yokohama and Kobe.

Finally, and closely related to the data on occupational origins, 33 percent of the men studied indicate that their families had occupied the statuses of nobility or of samurai during the feudal era, compared with about 6 percent of the population. Taken together with the data on occupations, it appears that the business leaders of modern Japan, like much else in the society, presents a picture of basic continuity and inheritance in a context of slow adaptation and change, despite the enormous social changes that have taken place.

\title{
Industrial Organization and Social Structure in Japan
}

\author{
Ken'ichi Tominaga
}

The University of Tokyo

The social background from which the industrial sociology in United States and the Betriebssoziolozie in Germany started in 1930's consisted in some important problems in these industrial societies that the development of big businesses brought about on the emerging masses of iudustrial workers. If that is the case, then there 


\title{
Industrial Organization in Japan
}

\section{- A New Frontier ố Industrial Sociology -}

\author{
Kunio Odaka \\ The Tniversity of Tokyo
}

\begin{abstract}
This is to make a few introductory remarks for the Symposium held during the 1960 Congress of the Japan Sociological Society, on which occasion the present writer served as chairman of the discussion meeting. This article, together with a brief introduction of each contributor to the Symposium, includes two sections dealing with the Japanese pattern of industrialization and the present position of industrial sociology in Japan.
\end{abstract}

\section{Social Characteristics of Japanese Business Leaders}

\section{Hiroshi Mannari \\ Krvansei Gakuin Uuiversity}

The comparative study of business elites in modern countries and changes in patterns of recruitment of these groups are receiving considerable attention in the present time. In the course of industrialization in Japan their business leaders have exerted important influences over Japanese socjety. Our concern is to learn who these leaders are; to learn about their social origins, their education and career patterns. We want further to compare the present-day business leadership of Japan with that of other countries to learn more of the similarities and differences between Japan and other modern nations.

On the basis of our pilot research, some parts of which were reported jointly with James C. Abegglen in "Leaders of Modern Japan: Social Origins and Mobility", Economic Development and Culutural Change, University of Chicago, October 1960, we have conducted an extensive questionnaire survey covering social origins, education, career and other experiences to a sample group of 1524 Japanese business leaders, who occupy the positions in top-management of the largest business enterpises in Japan as of the beginning of 1960 . We have received 1008 responses and we would like to discuss the social characteristics of Japanese business leaders out of the preliminary results of our collected data. Teese are summerized as the followiug. (A detail monograph of the research will be published elsewhere with the collaborator.)

Occupational Origins. About one-third of the top-level business leaders of modern Japan are sons of big businessmen or government officials, while these groups make up less than 3 percent of the population. Sons of farmers make up only about one-forth of this leadership group while they comprise one-half of the population, and among this group from rural back-grounds, sons of landlords are the largest proportion. Only one precent of laborers appear in leadership positions, although they make up 26 percent of this population. 